\title{
Effects of resistive exercise and stretching on the soleus muscle of ovariectomized rats
}

\author{
Efeitos do exercício resistido e alongamento no músculo sóleo de ratas ovariectomizadas \\ Efectos del ejercicio resistido y estiramiento en el músculo sóleo de ratas ovariectomizadas \\ Julye Leiko Ywazaki', Ana Paula Cunha Loureiro², Talita Gianello Gnoato Zotz \\ Luana Ribeiro Nascimento ${ }^{4}$, Douglas Vizzu Nobre ${ }^{4}$, Anna Raquel Silveira Gomes ${ }^{5}$
}

\begin{abstract}
I This study analyzed the effects of resistive exercise and/or stretching in the muscle morphology of ovariectomized rats. Seventy-five female Wistar rats $(218 \pm 22 \mathrm{~g}$ ) were divided into 8 groups: Control (CONTROL, n=5); Ovariectomy/Hysterectomy $(\mathrm{OH}, \mathrm{n}=10)$ : ovariectomized/hysterectomized and then waited 8 weeks for the onset of osteopenia. Stretching (STRET, $n=10$ ): manual stretching of the soleus muscle (10 repetitions of 60s), twice weekly; Ovariectomy/Hysterectomy and Stretching ( $\mathrm{OH}+\mathrm{STRET}, \mathrm{n}=10)$; Progressive Loading ( $\mathrm{PL}$, $n=10)$ : 4 sets of 10 repetitions, initial load $50 \%$ of body weight, increasing weekly until 70\%, three times a week. Progressive Loading and Stretching (PL+STRET, $n=10$ ); Ovariectomy/Hysterectomy and Progressive loading exercise ( $\mathrm{OH}+\mathrm{PL}, \mathrm{n}=10) ;$ Ovariectomy/Hysterectomy, Progressive Loading and Stretching $(\mathrm{OH}+\mathrm{PL}+\mathrm{STRET}, \mathrm{n}=10)$. Stretching and/or progressive loading were performed for 6 weeks. After 14 weeks, the female rats were euthanized to remove the soleus muscle. The following variables were assessed: body weight; muscle weight and length; number and length of sarcomeres and the muscle fiber cross-sectional area (MFCSA). Comparisons between the groups were performed with ANOVA one-way post hoc Tukey or Kruskall-Wallis ( $p<0.05)$. The body and muscle weights of ovariectomized rats submitted to exercise were higher than the intact ones. The $\mathrm{OH}$ and $\mathrm{OH}+\mathrm{PL}+\mathrm{STRET}$
\end{abstract}

increased the muscle length and the serial sarcomere number. $\mathrm{OH}$ presented the smallest MFCSA compared to all groups. Ovariectomy/hysterectomy induced sarcopenia, but the exercise's protocols were enough to prevent the loss of MFCSA. The increase in body weight associated to resistive training and stretching enhanced sarcomerogenesis of ovariectomized rats.

Keywords | Muscle Stretching Exercises; Musculoskeletal System; Sarcopenia; Rats.

RESUMO I O estudo analisou os efeitos do exercício resistido e/ou alongamento na morfologia muscular de ratas ovariectomizadas. Setenta e cinco ratas Wistar $(218 \pm 22 \mathrm{~g})$ foram divididas em 8 grupos: Controle (CONTROLE, $\mathrm{n}=5)$; Ovariectomia/histerectomia $(\mathrm{OH}$, $\mathrm{n}=10$ ): foram submetidas à ovariectomia/histerectomia e aguardaram oito semanas para instalação de osteopenia; Alongamento (ALONG, $n=10$ ): alongamento manual do músculo sóleo (10 repetições de 60s), duas vezes por semana; Ovariectomia/histerectomia e Alongamento $(\mathrm{OH}+\mathrm{ALONG}, \mathrm{n}=10)$; Exercício Resistido $(\mathrm{ER}, \mathrm{n}=10): 4$ séries de 10 repetições, carga inicial de $50 \%$ do peso corporal, aumentando semanalmente até $70 \%$, três vezes por semana; Exercício Resistido e Alongamento (ER+ALONG, $\mathrm{n}=10$ ); Ovariectomia/histerectomia e Exercício Resistido $(\mathrm{OH}+\mathrm{PL}, \mathrm{n}=10) ; \quad$ Ovariectomia/histerectomia, Exercício

\footnotetext{
Study developed at the Universidade Federal do Paraná/Pontifícia Universidade Católica do Paraná (PR), Brazil.

1 Physiotherapist, master of Science in Physical Education, Universidade Federal do Paraná - Curitiba (PR), Brazil.

2 Physiotherapist, master of Science in Gerontology, lecturer in Physiotherapy Under Graduation Course at Pontifícia Universidade Católica do Paraná - Curitiba (PR), Brazil.

3 Physiotherapist, PhD in Physical Education, lecturer in Physiotherapy Under Graduation Course at Universidade Federal do Paraná Curitiba (PR), Brazil.

${ }^{4}$ Physiotherapist - Curitiba (PR), Brazil.

${ }_{5}^{5}$ Physiotherapist, PhD, professor in Physiotherapy Under graduation Course and professor and advisor in Master of Science and PhD

Physical Education Programs at Universidade Federal do Paraná - Curitiba (PR), Brazil.
} 
Resistido e Alongamento $(\mathrm{OH}+\mathrm{ER}+$ Along, $\mathrm{n}=10)$. Alongamento e/ou Exercicio Resistido foram realizados durante 6 semanas. Após 14 semanas, as ratas foram submetidas à ortotanásia para remoção do sóleo. As seguintes variáveis foram avaliadas: peso corporal; peso e comprimento muscular; número e comprimento dos sarcômeros e área da secção transversa das fibras musculares (ASTFM). Comparação entre grupos foi realizada com ANOVA one way post hoc Tukey ou Kruskall-Wallis $(p<0,05)$. O peso corporal e muscular das ratas submetidas aos exercícios foram maiores do que as intactas. $\mathrm{O} \mathrm{OH}$ e $\mathrm{OH}+\mathrm{ER}+\mathrm{ALONG}$ aumentaram $\mathrm{O}$ comprimento e o número de sarcômeros. $\mathrm{O} \mathrm{OH}$ apresentou menor ASTFM em comparação com todos os grupos. Ovariectomia/ histerectomia induziu sarcopenia, mas os protocolos de exercícios foram suficientes para evitar a perda de ASTFM. O aumento do peso corporal associado ao exercício resistido e alongamento induziu sarcomerogenese nas ratas ovarectomizadas.

Descritores | Exercícios de Alongamento Muscular; Sistema Musculoesquelético; Sarcopenia; Ratos.

RESUMEN | El estudio analizó los efectos del ejercicio resistido y/o estiramiento en la morfología muscular de ratas ovarectomizadas. Se dividió setenta y cinco ratas Wistar (218 \pm 22 g) en 8 grupos: Control (CONTROL, n=5); ovariectomía/ histerectomía $(\mathrm{OH}, \mathrm{n}=10)$ : fueron sometidas a ovariectomía/ histerectomía y esperaron ocho semanas para la instalación de osteopenia; Estiramiento (ESTIR, n=10): estiramiento manual del músculo sóleo (10 repeticiones de 60s), dos veces por semana; ovariectomía/histerectomía y estiramiento ( $\mathrm{OH}+\mathrm{ESTIR,} n=10)$, ejercicio resistido ( $E R, n=10): 4$ series de 10 repeticiones, carga inicial de 50\% del peso corporal, aumentando semanalmente hasta 70\%, tres veces por semana; Ejercicio resistido y estiramiento ( $E R+E S T I R, n=10)$; ovariectomía/histerectomía y ejercicio resistido $(\mathrm{OH}+\mathrm{PL}, \mathrm{n}=10)$; ovariectomía/histerectomía, ejercicio resistido y estiramiento $(\mathrm{OH}+\mathrm{ER}+\mathrm{ESTIR}, \mathrm{n}=10)$. Se realizó estiramiento y/o ejercicio resistido durante 6 semanas. Después de 14 semanas, las ratas fueron sometidas a ortotanasia para la remoción del sóleo. Las siguientes variables fueron evaluadas: peso corporal; peso y longitud muscular; número y longitud de los sarcómeros y área de la sección trasversa de las fibras musculares (ASTFM). Se realizó una comparación entre grupos con ANOVA one way post hoc Tukey o Kruskall-Wallis ( $p$ $<0,05)$. El peso corporal y muscular de las ratas sometidas a los ejercicios fue mayor que el de las intactas. $\mathrm{El} \mathrm{OH}$ y OH+ER+ESTIR aumentaron la longitud y el número de los sarcómeros. El OH presentó menor ASTFM en comparación con todos los grupos. Ovariectomía/histerectomía indujo sarcopenia, más los protocolos de ejercicios fueron suficientes para evitar la pérdida de ASTFM. El aumento del peso corporal asociado al ejercicio resistido y estiramiento indujo sarcomerogénesis en las ratas sometidas a ovariectomía.

Palabras clave | Ejercicios de Estiramiento Muscular; Sistema Musculoesquelético; Sarcopenia; Ratos.

\section{INTRODUCTION}

The human aging process is occurring worldwide (12\% of the global population is elderly, $11 \%$ of people in Brazil are elderly) ${ }^{1}$. The physiological changes in the human body, especially the musculoskeletal, related to aging, are a recognized public health problem ${ }^{2}$. One of the more unavoidable consequences of aging in women, specifically post menopause, is the decline of ovarian hormones, mainly estrogen, which is associated to decrease in muscle mass and strength, an effect known as sarcopenia ${ }^{3}$.

The skeletal muscle changes related to aging can cause reductions in the cross-sectional area and number of the muscle fibers and also in motor units, followed by substitution for fat and connective tissue ${ }^{2}$.

Many of the physiological modifications associated with aging can be relieved and even reverted by physical exercise ${ }^{4}$. Resistive and stretching exercises are prescribed in training programs, but it is not clear, until now, what the isolated effects are and what association these exercises have in the skeletal muscle of the elderly $^{5}$. It has been described that stretching and/or resistive exercises can prevent or improve muscular strength, flexibility, balance and mobility in elderly ${ }^{5,6}$.

Ovariectomized rats have been used as an animal model to mimic postmenopausal women for investigating the effects of exercise on bone and skeletal muscle loss $^{7}$. Furthermore, stretching and/or resistive training can increase the serial sarcomere number and muscle fiber cross-sectional area of young rats ${ }^{8,9}$. Furthermore, in a recent study with aging female rats submitted to stretching exercise, an antifibrotic action was also detected ${ }^{10}$. 
Nevertheless, despite the resistive exercise, stretching, and their association being commonly used, the cellular mechanisms of musculoskeletal adaptation to these exercises, especially in the absence of estrogen, i.e., after ovariectomy, are still unknown. Therefore, it was hypothesized that a progressive loading exercise program associated to stretching could have a stimulatory effect on the muscle mass of ovariectomized rats. Thus, the objective of this study was to investigate the effects of resistive training and/or stretching in the soleus muscle morphology of ovarietomized and histerectomized female rats.

\section{METHODOLOGY}

This study was conducted with female Wistar rats, following the international ethics standard in animal experiments ${ }^{11}$ and was approved by the Ethics Committee of the Pontifícia Universidade Católica do Paraná (PUC), number 127.07 CEUA PUCPR and Universidade Federal do Paraná, number 23075.010217/2010-30. The female rats were kept in standard plastic cages under environmentally controlled conditions (luminosity: 12 hour light/dark cycles) with free access to water and pelleted feed, at the PUC/PR vivarium.

The rats were divided into 8 groups: Control (CONTROL, $n=5$ ), were kept intact;

Ovariectomy/Hysterectomy $(\mathrm{OH}, \mathrm{n}=10)$, subjected to ovariectomy/hysterectomy;

Stretching (STRET, $\mathrm{n}=10$ ), subjected only to the stretching protocol;

Ovariectomy/Hysterectomy and Stretching (OH+STRET, $\mathrm{n}=10)$, subjected to ovariectomy/ hysterectomy and to stretching;

Progressive Loading (PL, $n=10$ ), subjected to the progressive loading exercise;

Progressive Loading and Stretching (PL+STRET, $\mathrm{n}=10$ ), subjected to progressive loading exercise and to stretching;

Ovariectomy/Hysterectomy and Progressive Loading ( $\mathrm{OH}+\mathrm{PL}, \mathrm{n}=10)$, subjected to ovariectomy/ hysterectomy and to progressive loading exercise;

Ovariectomy/Hysterectomy and Progressive Loading and Stretching $(\mathrm{OH}+\mathrm{PL}+\mathrm{STRET}, \mathrm{n}=10)$, subjected to ovariectomy/hysterectomy, progressive loading and stretching exercises. The protocols of the progressive loading exercise were performed 3 times a week and stretching twice a week, for 6 consecutive weeks.
All rats, 26 weeks old, were subjected to vafter completing a 14-week experimentation period, as shown in the flowchart of the study (Figure 1).

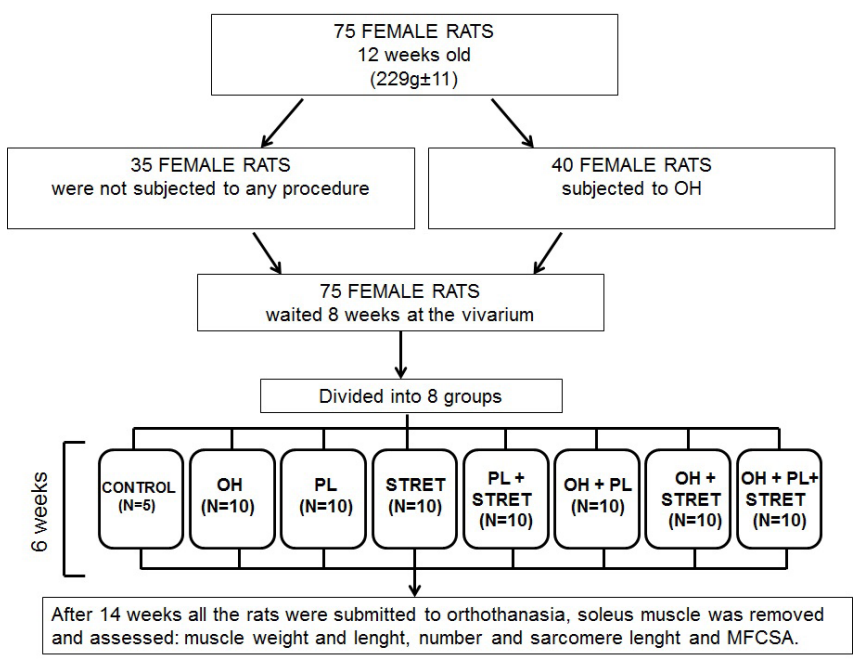

Figure 1. Flowchart of the study. CONTROL, control group. $\mathrm{OH}$, ovariectomy/hysterectomy group. PL, progressive loading exercise group. STRET, stretching group. PL+STRET, progressive loading and stretching group. $\mathrm{OH}+\mathrm{PL}$, ovariectomy/ hysterectomy and progressive loading group. OH+STRET, ovariectomy/hysterectomy and stretching group. $\mathrm{OH}+\mathrm{PL}+\mathrm{STRET}$, ovariectomy/hysterectomy, progressive loading and stretching group. MFCSA: muscle fiber cross sectional area

\section{Experimental surgical procedure}

Each group was initially kept at the vivarium for 8 weeks. However, the rats from the groups $\mathrm{OH}$; $\mathrm{OH}+\mathrm{STRET} ; \mathrm{OH}+\mathrm{PL} ; \mathrm{OH}+\mathrm{PL}+\mathrm{STRET}$ were submitted to ovariectomy and hysterectomy surgery, with the objective of ceasing the production of estrogen and held for 8 weeks at the vivarium until the onset of the osteopenia condition, as described by Kalu (12). During the first 8 weeks it was not performed experimental procedure and all the rats were kept ad labitum. After this period, the ovariectomized/hysterectomized rats were divided into: $\mathrm{OH} ; \mathrm{OH}+\mathrm{STRET} ; \mathrm{OH}+\mathrm{PL}$; $\mathrm{OH}+\mathrm{PL}+\mathrm{STRET}$. The $\mathrm{OH}$ rats did not undergo any exercise protocol and were weighed weekly.

For the ovariectomy and hysterectomy surgery, the rat was fistly anesthetized via intraperitoneal (Tiopental Sódico, $0,025 \mathrm{~g} / \mathrm{ml}$ ). After, positioned in right lateral decubitus for trichotomy, $2 \mathrm{~cm}$ under the last rib, the area was sterilized with 5\% iodinated alcohol, and then an incision was performed using a sterilized surgical bladeAC (MedBlad).

After the incision, a small suture was made on the uterine base, with black resorbable nylon followed by 
the ovariectomy (removal of the ovary) on both sides and hysteriectomy (removal of the uterus). Finally, the uterus base and muscle was sutured with black resorb able nylon $(E T H I C O N, 3-0,70 \mathrm{~cm})$ and external sutures (skin) were made with non-resorb able nylon (ETHICON, 6-0, 45cm).

\section{Stretching protocol}

One of the researchers manually immobilized the female rat while another stabilized and passively and manually kept the ankle joint in maximum dorsiflexion in order to stretch the left soleus muscle, without anesthetic effect ${ }^{13}$. The stretching protocol consisted of 10 repetitions of 1 minute each with 45 seconds rest between each repetition, controlled with a chronometer (Technos) ${ }^{13,14}$. The stretching was performed twice a week, every other day, over 6 weeks, totaling 12 stretching sessions, always at the same time of the day.

\section{Progressive loading exercise}

The progressive loading protocol, being resistive exercise, was performed in a container (height: $80 \mathrm{~cm}$; diameter: $30 \mathrm{~cm}$ ), of $60 \%$ warm water $\left(\right.$ at $30^{\circ} \mathrm{C}$ ). The training program was carried out by fixing an additional load on the animal's body using an appropriate vest that allowed the animal to jump without the vest slipping off its body ${ }^{7}$.

The animal started the progressive loading training protocol, which consisted of jumping into water. The load was established by the following manner: the load was placed on the animal's body initially corresponding to $50 \%$ of its body weight, increasing $10 \%$ fortnightly until reaching $70 \%$ of its body weight. After, the animals were put in a compartment with water, to perform the jumps. The load added to the animal's body did not allow it to float or swim. Thus, when the rat was put in the container, the rear paw was able to touch the depth of the tank, and then, to make the leap to reach the surface of the tank, an eccentric contraction was performed, followed by the concentric of the triceps surae muscle. The training protocol was constituted of 4 bouts of 10 jumps, with a 60 second rest (Technos chronometer) between each bout ${ }^{7}$. The sessions were performed three times a week (Monday, Wednesday and Friday) throughout 6 weeks and the sessions were performed at the same time of the day.

\section{Orthothanasia of the animals and muscle dissection}

After 14 weeks of the experiment, the female rats were anesthetized, with an intraperitoneal injection of ketamine $(95 \mathrm{mg} / \mathrm{kg})$ and Xilazine $(12 \mathrm{mg} / \mathrm{kg})$, for dissection of the left soleus muscle. Afterwards, and under anesthetic effect, the orthothanasia was induced with an intracardiac injection of KCI (3M).

During the dissection, the muscle was periodically dropped with saline solution $(\mathrm{NaCl} 0,9 \%)$, to avoid tissue dryness. After the dissection, the soleus muscle was weighed alone, using a precision analytical balance (Mettler/Toledo). Then the muscle was spread on a plane surface (Styrofoam) to measure the muscle length, using a caliper rule (Vonder). The soleus was divided longitudinally with a blade (Feather), into two equal parts. The medial half was processed for serial sarcomeres number counting and the lateral half was used for the muscle fiber morphometry.

\section{Procedure for counting the serial sarcomere number}

The medial portion of the left soleus muscle was fixed for three hours in glutaraldehyde (2.5\%), kept for 2 days in nitric acid (30\%) and stored in a solution of glycerol diluted in distilled water $(50 \%)^{15}$.

Thereafter, ten muscle fibers from each soleus muscle were teased out and fixed in a histological slide by gelatina-glicerina. Afterwards, the serial sarcomere number was counted along $300 \mu \mathrm{m}$ of each muscle fiber, in a light microscope (objective 100x in immersion; microscope Nikon, Eclipse E200). The quantification was performed in a binocular microscope, Olympus BX40 with digital camera DP71 coupled in objective 100x of immersion in the Ficologia laboratory, at the Botanical Department of Biological Sciences Sector at the Federal University of Paraná (UFPR).

The total serial sarcomere number and the length of the sarcomeres in each muscle fiber were estimated by the correlation between the number of sarcomeres identified in 3 fields of $100 \mu \mathrm{m}$ totaling $300 \mu \mathrm{m}$ along the muscle fiber and the total length of the muscle, as described by Williams and Goldspink ${ }^{16}$. In this study, the length of the sarcomeres along the muscle fibers were considered homogeneous ${ }^{8}$. 


\section{Procedures for histological analysis}

The lateral portion of the soleus muscle was used to evaluate the muscle fiber cross-sectional area (MFCSA), fixed in 10\% formalin, included in paraffin, sectioned transversely $(8 \mu \mathrm{m})$ in microtome (Olympus) and stained with hematoxylin and eosin (HE).

For the photomicrography of histological sections a light photomicroscope (Olympus BX50) was used and the images were captured by a video-imaging system (camera Sony CCD IRIS) through the Software Image Pro Plus 4.5, in the Laboratory of Experimental Pathology at Pontifícia Universidade Católica do Paraná (PUC/PR, Campus Curitiba). The photomicrographs are shown in Figure 2.

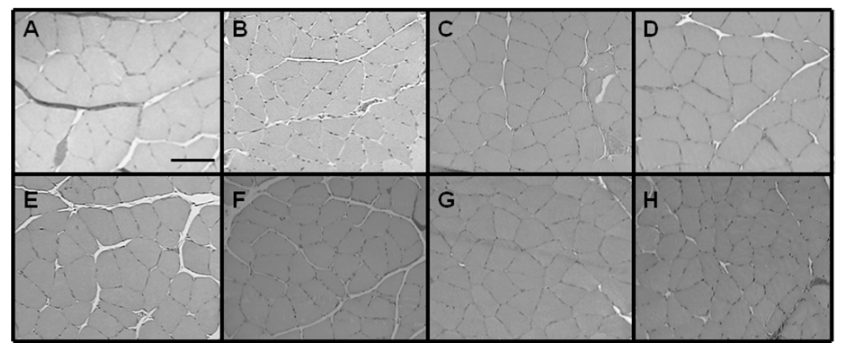

A, Control, muscle fibers showing a normal aspect, and $\mathbf{B}$, ovariectomy/hysterectomy group $(\mathrm{OH})$ presenting muscle fiber atrophy (sarcopenia). C, progressive loading exercise group (PL) with muscle fibers showing a normal aspect. D, stretching group (STRET) with muscle fibers showing a normal aspect. E, progressive loading and stretching group (PL+STRET) with muscle fibers showing a normal aspect. $\mathbf{F}$, ovariectomy/hysterectomy and progressive loading group $(\mathrm{OH}+\mathrm{PL})$ with muscle fibers showing a normal aspect. G, ovariectomy/hysterectomy and stretching group $(\mathrm{OH}+\mathrm{STRET})$ with muscle fibers showing a normal aspect. $\mathbf{H}$, ovariectomy/hysterectomy, progressive loading and stretching group $(\mathrm{OH}+\mathrm{PL}+\mathrm{STRET})$ with muscle fibers showing a normal aspect. Bar: $30 \mu \mathrm{m}$ for all panels

Figure 2. Effects of resistive exercise and stretching on the soleus muscle morphology of ovariectomized rats. Photomicrographs (100x) of soleus cross-sections stained by hematoxylin and eosin

From each muscle the cross-sectional area of 100 muscle fibers chosen by random from the region of the muscle belly of the histological section were measured, as described by Coutinho et al. ${ }^{8}$. The MFCSA was measured by the UTHSCSA Image Tool 3.0 software (developed by the University of Texas Health Science Center at San Antonio, Texas, and available at http:// ddsdx.uthscsa.edu/dig/itdesc.html).

\section{Analysis of results}

The following variables were analyzed: initial and final body weight, muscle weight, muscle length, serial sarcomere number, sarcomere length, cross-sectional area of the fibers (MFCSA) of the left soleus muscle.

To test the homogeneity and normality we performed Levene and Shapiro-Wilk's tests, respectively. Data that showed normal distributions was considered parametric (Sarcomere number; Muscle fiber cross-sectional area) and the comparisons among the groups were made by analysis of variance (ANOVA) one way post hoc Tukey. For non-parametric results (Body weight; Muscle weight; Muscle length; Sarcomere length) KruskalWallis was used. The level of significance was set at $\leq$ 0.05 . All results are reported as the mean \pm standard error of the mean.

\section{RESULTS}

\section{Body weight}

The results presented normal distribution $(\mathrm{p}=0.08)$ but not homogeneous $(\mathrm{p}=0.03)$. The final body weight of PL+STRET $(p \leq 0.05)$ and PL $(p \leq 0.05)$ was lower than the CONTROL, OH+PL, OH+STRET and the $\mathrm{OH}+\mathrm{PL}+\mathrm{STRET}$. The results are shown in Table 1.

Table 1. Effects of resistive exercise and stretching on the body weight of ovariectomized rats

\begin{tabular}{ccccc} 
Group & $\begin{array}{c}\text { Initial body } \\
\text { weight }(\mathbf{g})\end{array}$ & $\begin{array}{c}\text { final body } \\
\text { weight } \\
(\mathbf{g})\end{array}$ & $\begin{array}{c}\text { Relative } \\
\text { difference } \\
(\%)\end{array}$ & $\begin{array}{c}\text { p } \\
\text { paired } \\
\text { t-Test }\end{array}$ \\
\hline CONTROL $^{\#}$ & $247 \pm 3$ & $327 \pm 8$ & $24 \pm 4$ & 0.002 \\
OH & $242 \pm 5$ & $310 \pm 3$ & $22 \pm 3$ & 0.0001 \\
PL & $215 \pm 3$ & $249 \pm 9$ & $13 \pm 11$ & 0.01 \\
STRET & $219 \pm 6$ & $298 \pm 4$ & $26 \pm 7$ & 0.0001 \\
PL+STRET & $225 \pm 3$ & $253 \pm 7$ & $11 \pm 8$ & 0.009 \\
OH+PL & $223 \pm 4$ & $342 \pm 8$ & $35 \pm 2$ & 0.0001 \\
OH+STRET $^{\S}$ & $236 \pm 7$ & $325 \pm 8$ & $27 \pm 5$ & 0.0001 \\
OH+PL+STRET $^{+}$ & $228 \pm 5$ & $317 \pm 7$ & $28 \pm 7$ & 0.0001
\end{tabular}

CONTROL, control group. OH, ovariectomy/hysterectomy group. PL, progressive loading exercise group. STRET, stretching group. PL+STRET, progressive loading and stretching group. $\mathrm{OH}+\mathrm{PL}$, ovariectomy/hysterectomy and progressive loading group. OH+STRET, ovariectomy/ hysterectomy and stretching group. $\mathrm{OH}+\mathrm{PL}+\mathrm{STRET}$, ovariectomy/hysterectomy, progressive loading and stretching group. ${ }^{+}$compared with PL+STRET $(p=0.02)$ and PL $(p=0.01)$. "compared with PL+STRET $(p=0.0001)$ and PL $(p=0.00007)$. " compared with PL+STRET $(p=0.03)$ and PL $(p=0.02) .{ }^{\S}$ compared to $P L+S T R E T(p=0.009)$ and $P L(p=0.006)$. The values are represented as mean \pm standard error of the mean

\section{Muscle weight}

The data presented normality $(\mathrm{p}=0.32)$ and homogeneity $(\mathrm{p}=0.05)$. The muscle weights of STRET, $\mathrm{OH}+\mathrm{STRET}$ and $\mathrm{OH}+\mathrm{PL}+\mathrm{STRET}$ were higher when compared to PL+STRET $(p \leq 0.05)$ and PL $(p \leq 0.05)$. The $\mathrm{OH}+\mathrm{PL}$ was superior compared to PL+STRET 
( $p=0.0001), P L(p=0.0002)$ and $\mathrm{OH}(p=0.005)$. The results are shown in Table 3.

Table 3. Effect of resistive exercise and stretching on the muscle weight (MW) in grams ( $\mathrm{g}$ ) and muscle fiber cross sectional area (MFCSA) in square micrometer $\left(\mu \mathrm{m}^{2}\right)$

$\begin{array}{cccc}\text { Group } & \text { Absolute MW } & \begin{array}{c}\text { MW } \\ \text { standardized }\end{array} & \text { MFCSA } \\ \text { CONTROL } & 0.13 \pm 0.01 & 0.004 \% & 2276 \pm 112.23 \\ \text { OH } & 0.12 \pm 0.001 & 0.0009 \% & 1396 \pm 77.97^{5} \\ \text { PL } & 0.11 \pm 0.004 & 0.002 \% & 2173 \pm 150.51 \\ \text { STRET } & 0.14 \pm 0.008 & 0.003 \% & 2393 \pm 41.52 \\ \text { PL+STRET } & 0.10 \pm 0.005 & 0.001 \% & 1952 \pm 118.32 \\ \text { OH+PL } & 0.16 \pm 0.007^{2} & 0.002 \% & 2213 \pm 81.48 \\ \text { OH+STRET } & 0.15 \pm 0.005^{3} & 0.002 \% & 2096 \pm 149.74 \\ & & & \\ \text { OH+PL+STRET } & 0.15 \pm 0.006^{4} & 0.001 \% & 2302 \pm 100.34\end{array}$

CONTROL, control group. OH, ovariectomy/hysterectomy group. PL, progressive loading exercise group. STRET, stretching group. PL+STRET, progressive loading and stretching group $\mathrm{OH}+\mathrm{PL}$, ovariectomy/hysterectomy and progressive loading group. OH+STRET, ovariectomy/ hysterectomy and stretching group. OH+PL+STRET, ovariectomy/hysterectomy, progressive loading and stretching group. MW standardized muscle weight/body weight $1 \mathrm{p} \geq 0.05 \mathrm{com}$ pared $\mathrm{PL}(\mathrm{p}=0.0002)$ and $\mathrm{OH}(\mathrm{p}=0.005) .{ }^{3} \mathrm{p} \geq 0.05$ compared with PL+STRET $(p=0.0002)$ and PL $(p=0.004) .{ }^{4} p \geq 0.05$ compared with PL+STRET $(p=0.0006)$ and PL $(p=0.01) .{ }^{5}$ compared with all groups $(\mathrm{OH}+\mathrm{PL}+\mathrm{STRET}, p=0.0001) ; \mathrm{OH}+\mathrm{PL}, p=0.0001) ;(P L+S T R E T, p=0.01) ;(P L, p=0.0002)$; $(\mathrm{OH}+\mathrm{STRET}, \mathrm{p}=0.0008) ;(\mathrm{STRET}, \mathrm{p}=0.0001)$ and $(\mathrm{CONTROL}, \mathrm{p}=0.002)$. The values are represented as mean \pm standard error of the mean

\section{Muscle length}

The results were normally distributed $(\mathrm{p}=0.19)$, but not homogeneous $(p=0.03)$. The OH+PL+STRET presented greater muscle length when compared to PL $(p=0.02)$, CONTROL $(p=0.003), O H+S T R E T$ $(\mathrm{p}=0.01)$ and STRET $(\mathrm{p}=0.03)$.

The $\mathrm{OH}+\mathrm{PL}$ exhibited greater muscle length compared to the PL, CONTROL, OH+STRET and STRET ( $\mathrm{p}=0.03, \mathrm{p}=0.04, \mathrm{p}=0.02$ and $\mathrm{p}=0.04$ respectively). The results are shown in Table 2.

\section{Serial sarcomere number}

The results showed a normal distribution $(\mathrm{p}=0.23)$ and were homogeneous $(\mathrm{p}=0.15)$. The rats subjected to ovariectomy/hysterectomy, progressive loading and stretching $(\mathrm{OH}+\mathrm{PL}+\mathrm{STRET})$ had a greater serial sarcomere number compared to CONTROL $(\mathrm{p}=0.001)$, $\mathrm{OH}+\operatorname{STRET}(\mathrm{p}=0.001)$ and STRET $(\mathrm{p}=0.02)$.

The $\mathrm{OH}$ group showed a greater serial sarcomere number compared to PL $(p=0.007), P L+S T R E T$ $(\mathrm{p}=0.017)$, CONTROL $(\mathrm{p}=0.0003)$, OH+STRET $(\mathrm{p}=0.0002)$ and STRET $(\mathrm{p}=0.003)$. The results are shown in Table 2.

Table 2. Effects of resistive exercise and stretching on the muscle length, serial sarcomere number and sarcomere length of ovariectomized rats

$\begin{array}{cccc}\text { GROUP } & \text { ML }(\mathrm{mm}) & \text { ESSN } & \text { SL }(\mu \mathrm{m}) \\ \text { CONTROL } & 21.28 \pm 1.23 & 10.101 \pm 521.4 & 2.07 \pm 0.2 \\ \text { OH } & 26.36 \pm 0.82 & 14.090 \pm 791.85^{3} & 1.92 \pm 0.14 \\ \text { PL } & 21.57 \pm 0.66 & 11.070 \pm 496.74 & 1.99 \pm 0.06 \\ \text { STRET } & 21.70 \pm 0.27 & 10.837 \pm 270.54 & 1.99 \pm 0.04 \\ \text { PL+STRET } & 23.80 \pm 0.68 & 11.303 \pm 645.56 & 2.02 \pm 0.03 \\ \text { OH+PL } & 26.5 \pm 0.61 & 12.219 \pm 170.63 & 2.08 \pm 0.03 \\ \text { OH+STRET } & 21.42 \pm 1.16 & 9.973 \pm 636.93 & 2.19 \pm 0.09 \\ \text { OH+PL+STRET } & 27.1 \pm 0.72^{2} & 13.540 \pm 571.774 & 2.02 \pm 0.06\end{array}$

Effect of resistive exercise and stretching on the muscle length $(\mathrm{ML})$ in milimeters $(\mathrm{mm})$, estimated serial sarcomere number (ESSN) and sarcomere length (SL) in micrometers ( $\mu \mathrm{m}$ ). CONTROL, control group. OH, ovariectomy/hysterectomy group. PL, progressive loading exercise group. STRET, stretching group. PL+STRET, progressive loading and stretching group. $\mathrm{OH}+\mathrm{PL}$, ovariectomy/hysterectomy and progressive loading group. OH+STRET, ovariectomy/ hysterectomy and stretching group. OH+PL+STRET, ovariectomy/hysterectomy, progressive loading and stretching group. 1 compared with PL $(p=0.03)$, Control $(p=0.04), O H+S T R E T$ $(p=0.02)$ and STRET $(p=0.04) .2$ compared with ER $(p=0.02)$, Control $(p=0.003), O H+$ STRET $(p=0.01)$ and STRET $(p=0.03) .3$ compared with PL $(p=0.007), \operatorname{PL}+\operatorname{STRET}(p=0.017)$, Control $(p=0.003), O H+\operatorname{STRET}(p=0.0002)$ and STRET $(p=0.003) .4$ compared with Control $(p=0.001)$, $\mathrm{OH}+$ STRET $(p=0.001)$ and STRET $(p=0.02)$. The values are represented as mean \pm standard error of the mean

\section{Sarcomere length}

The data showed a normal distribution $(\mathrm{p}=0.11)$ but not homogeneous $(p=0.000013)$. There was no statistical significance in sarcomere length. The results are presented in Table 2 .

\section{Muscle fiber cross sectional area (MFCSA)}

The results showed a normal distribution $(\mathrm{p}=0.11)$ and were homogeneous $(p=0.41)$. The rats subjected to ovariectomy and hysterectomy $(\mathrm{OH})$ had the lowest crosssectional area of the soleus muscle compared to all groups: $\mathrm{OH}+\mathrm{PL}+\mathrm{STRET} \quad(\mathrm{p}=0.0001), \mathrm{OH}+\mathrm{PL} \quad(\mathrm{p}=0.0001)$, PL+STRET ( $\mathrm{p}=0.01), \mathrm{PL}(\mathrm{p}=0.0002), \mathrm{OH}+\mathrm{STRET}$ $(\mathrm{p}=0.0008)$, STRET $(\mathrm{p}=0.0001)$ and CONTROL $(\mathrm{p}=0.002)$. The results are displayed in Table 3.

\section{DISCUSSION}

The outcomes of this study showed that ovariectomy/ hysterectomy induced sarcopenia as assessed by the decrease in cross-sectional area of soleus muscle fibers. 
However, the protocols of resistive exercise associated or not to stretching, were enough to prevent the loss in the MFCSA of ovariectomy/hysterectomy rats. Furthermore, the overload of body weight associated with the stretching and resistive exercise induced the sarcomerogenesis in ovariectomy/hysterectomy rats.

Ovariectomy/hysterectomy, used in this study, is one of the experimental models to mimic menopause. According to Cooper ${ }^{17}$ sarcopenia is more pronounced in women due to an accelerated loss of muscle mass, bone mass density and muscle strength occuring at an earlier age than in men, around the time of menopause, caused by a decrease in estrogen levels. The muscle loss is primarily due to an imbalance between muscle protein synthesis and muscle protein breakdown and the increase of connective tissue and fat, reduction in the muscle fiber cross sectional area and a decrease in the estrogen muscle receptor ${ }^{18}$. In addition, McClung et al. ${ }^{19}$ observed that while ovarietomized rats took 28 days to recover the myofiber cross-sectional area when kept free in the cages, those ovariectomized with 17 -estradiol replacement took only 14 days. The authors concluded that myofiber growth, myofiber regeneration, and extracellular matrix remodeling are estrogen-sensitive components of soleus muscle mass recovery from disuse atrophy.

In this study, all groups showed a weight gain compatible with the normal growth of the animal. However, the body weight gain of rats submitted to ovariectomy/ hysterectomy associated with exercise protocols and the control group was higher when compared to the groups which performed resistance exercise associated or not with stretching (PL+STRET or PL).

These results demonstrated that the isolated resistive exercise or associated to stretching interfered differently with body weight gains in intact and ovariectomized/ hysterectomized rats.

The lower body weight gain of intact rats could be attributed to a resistive exercise protocol, performed 3 times a week, or its association with stretching, i.e., exercising 5 times a week. The rats submitted only to stretching (twice a week) had a weight gain similar to the group control. Thus, the frequency of intervention between 3 to 5 times a week may have interfered in the weight gain of the animals. However, these exercise protocols performed at these frequencies ( 3 to 5 times a week) did not prevent the gain of body weight in ovariectomized/hysterectomized female rats, suggesting an increase in body fat due to hypoestrogenism ${ }^{20}$.
The body weight gain and accumulation of body fat seems to result from a pattern of changes in diet and reduced physical activity, related to age, or the interaction among these factors ${ }^{20-22}$. Thus, these studies could explain the fact that the rats which performed exercises at higher weekly frequency ( 3 to 5 times a week), presented reduced body weight gains compared to the control group, that did not do any type of exercise.

However, in females, total body fat occurs, preferably by internal accumulation of body and intramuscular $\mathrm{fat}^{20}$. These changes seem to be the most likely pattern of behavior of adiposity with the aging process ${ }^{20,23}$. Thus, this process could explain the increase in body and muscle weights of ovariectomized/hysterectomized rats subjected to resistive exercise and its association with the stretching compared with the intact rats subjected to the same exercise protocols.

The increase in muscle weight presented by the groups submitted to ovariectomy/ hysterectomy and which performed resistance exercise, stretching, or both, compared with rats that performed only exercise protocols, may be related to the decrease of estrogen, as has also been observed by other authors ${ }^{7}$. Estrogen is responsible for the structural homeostasis of body fluids, so the increase in muscle weight can be attributed to the accumulation of fat in the perimysium and endomysium, as observed in sarcopenic muscles ${ }^{24}$. Therefore, exercise protocols performed were not sufficient to prevent muscle weight gains in ovariectomized/hysterectomized rats.

The increase in body and muscle weights, observed in this study, may have induced the increase in muscle length and the serial sarcomere number of the ovariectomized/ hysterectomized rats, which performed resistive exercise and the association with stretching. This outcome suggests that the overload due to the body weight, associated with the load to perform resistive exercise, should have induced sarcomerogenesis. According to $\mathrm{Wu}$ et al..$^{25}$ mechanical loading and contractile activity play critical roles in the regulation of muscle mass and altered loading can lead to the structural remodeling of skeletal muscle.

Experimental studies have found that skeletal muscle increases its length by adding sarcomeres along the muscle fibers, with consequent weight gains and increases in protein synthesis ${ }^{15,16,26}$. Thus, the skeletal muscle fibers can adapt according to functional demand, with the possible removal or addition of serial sarcomere numbers ${ }^{27}$.

Thus, the increase in body and muscle weight, muscle length and serial sarcomere number in the 
ovariectomized/hysterectomized groups, which performed resistive exercise and its association with stretching, could be attributed to the increased demand that the soleus muscle was submitted. Tabary et $\mathrm{al}^{27}$ found that when the soleus muscle was immobilized in the shortened position, there occurred a decrease of $40 \%$ in the serial sarcomere number. However, when the rats were kept free, i.e., without immobilization, for four weeks, the soleus muscle showed similar serial sarcomere number to the non-immobilized control group. Consequently, it can be concluded that skeletal muscle responds according to the functional demands placed upon it.

This study showed that the decrease of estrogen induced by ovariectomized/hysterectomized rats decreased the cross-sectional area of soleus muscle fibers, i.e., sarcopenia. Nevertheless, comparing ovariectomized/ hysterectomized rats to rats that performed resistive exercise and/or stretching, it could be observed that the exercise protocols were enough to prevent sarcopenia.

McClung et al. ${ }^{19}$ observed that the MFCSA of ovariectomized rats was able to recover compared to rats subjected to suspension of the lower limbs. Therefore, these authors observed that the soleus muscle mass of intact animals recovered by around the 7th day, whereas the ovariectomized rats' muscle masses did not recuperate until the 14 th day. In the ovariectomized rats, MFCSA remained 42\% lower than the intact rats.

Kokkonen et al. ${ }^{28}$ evaluated the effects of the combination of resistive exercise with stretching on muscle strength of young subjects, beginners in strength training. The exercise protocol was performed on alternate days, i.e., the day on which the strength training was performed, the stretching was not performed, and vice versa. These authors found an increase in the muscle strength of subjects who performed strength and stretching training, when compared with subjects who performed only the strength training. The researchers suggested that strength gains could be related to morphological changes, resulting from an increase in protein synthesis, in muscle length, in the serial sarcomere number and cross-sectional area of muscle fibers ${ }^{8,28}$.

In this study, we found an increase in the serial sarcomere number of ovariectomized/hysterectomized rats submitted to the association of resistive exercise and stretching. In addition, exercise protocols both on ovariectomized/hysterectomized, and on intact rats, were enough to prevent a loss in the cross-sectional area of the muscle fibers.
Some studies have reported that skeletal muscle and connective tissue's morphological adaptations depend on the type, intensity, duration and frequency of the exercises ${ }^{8,9,29}$. The muscular changes depend on mechanotransduction, which is the ability of the cell to sense, process, and respond to mechanical stimuli, regulating the muscle mass ${ }^{30}$. The muscular plasticity can affect the flexibility and the strength capacity ${ }^{31}$. Cação-Benedini et $\mathrm{al}^{29}$ ) investigated the effects of a single stretching session applied to the immobilized soleus muscle of young rats, and found an increase in the concentration of type III collagen, which remained for three days. In the same study, type I collagen showed lower concentrations in comparison to type III collagen. Zotz et al. ${ }^{10}$ also verified an increased percentage of immunopositive area of type III collagen and a decrease in the type I collagen of aged, female rats. Thus, stretching exercises, performed on young and aged rats, can modulate the connective tissue turnover.

Swank et al. $^{6}$ observed an increase in the range of motion in elderly individuals who performed the association of the stretching exercise with loads $(0.45$ to $1.35 \mathrm{~kg}$ ) when compared with those who performed only stretching exercises. Thus, the weight and muscle length gains, and the increase of serial sarcomere number identified in the ovariectomized/hysterectomized rats, which performed resistive exercise associated with stretching, within the limits, could be extrapolated to the human outcomes reported by Swank et al. ${ }^{6}$. Therefore, these findings suggest that stretching associated with loads can increase sarcomerogenesis of muscles in the absence of estrogen.

Marquete al. ${ }^{32}$ found a reduction of MMP-2 in the soleus muscle of ovariectomized rats, however, when the rats were subjected to resistive exercise, the reduction of MMP-2 was minimized.

This study presented some limitations including the absence of estrous cycling analysis and skeletal muscle estrogen receptors, to help understand the effects of the hormone's decline in post ovariectomy/hysterectomy and its association with exercise on skeletal muscle. In addition, the force to promote the stretching was not quantified, which could be solved by using a device with a load cell, as mentioned by Zotz et al. ${ }^{10}$

In this study, there was no connective tissue and molecular analysis, such as to evaluate the gene expressions related to sarcopenia and hypertrophy. Thus, it is suggested that future studies should investigate the molecular mechanisms responsible for sarcopenia 
and sarcomerogenesis induced by ovariectomized rats subjected to stretching and/or resistive exercise protocols.

\section{CONCLUSION}

Sarcopenia detected in this study was induced by a hysterectomy/ovariectomy procedure, but it was prevented by exercise. The overload of body weight, associated or not with exercise induced sarcomerogenesis in ovariectomized rats. This study demonstrated that the skeletal muscle atrophy caused by estrogen decline could be attenuated by resistive and or stretching exercise, suggesting clinical applications in humans.

\section{ACKNOWLEDGEMENTS}

We are thankful to Rafael Zotz, Misael Gomes Barbosa and Ana Paula Camargo Martins, from PUC/ PR for the technical support in experimental and laboratorial procedures. We are grateful to Professor Thelma Veiga Ludwig, from the Botanics Department of the Universidade Federal do Paraná (UFPR) for the technical support to use the photomicroscope.

\section{REFERENCES}

1. Who. World Health Organization.Geneva: World health statistics 2015.

2. Ryall, J.G.; Schertzer, J.D.; Lynch, G.S. Cellular and molecular mechanisms underlying age-related skeletal muscle wasting and weakness. Biogerontol. 2008; 9:213-28.

3. Cruz-Jentoft, A.J.; Baeyens, J.P.; Bauer, J.; Boirie, Y.; Cederholm, T.; Landi, F.; Martin, F.C.; Michel, J.P.; Rolland, Y.; Schneider, S.M.; Topinková, E.; Vandewoude, M.; Zamboni, M. Sarcopenia: European consensus on definition and diagnosis. Age Ageing 2010;39:412-23.

4. Leite RD, Prestes J, Pereira GB; Shiguemoto GE, Perez SE. A. Menopause: highlighting the effects of resistance training. J Sports Med. 2010;31:761-7.

5. Bird M, Hill KD, Ball M, Hetherington S, Williams AD. The longterm benefits of a multi-component exercise intervention to balance and mobility in healthy older adults. Arch Gerontol Geriatr. 2011;52(2):211-6.

6. Swank AM, Funk DC.; Durhan MP, Roberts S. Adding weights to stretching exercise increases passive range of motion for healthy elderly. J Strength Cond Res. 2003;2(17):374-8.

7. Renno AM, Gomes ARS, Nascimento RB, Salvini T, Parizoto $N$. Effects of a progressive loading exercise programo $n$ the bone and skeletal muscle properties of female osteopenic rats. Exp Gerontol. 2007;42(6):517-22.
8. Coutinho EL, Gomes ARS, França CN, Oishi J, Salvini TF. Effect of passive stretching on the immobilized soleus muscle fiber morphology. Braz J Med Biol Res. 2004;37:1853-61.

9. Secchi KV, Morais CP, Cimatti PF, Tokars E, Gomes ARS. Efeito do alongamento e do exercício contra-resistido no músculo esquelético de rato. Rev Bras Fisioter. 2008;12(3):228-34.

10. Zotz TG, Capriglione LG, Zotz R, Noronha L, Viola De Azevedo ML, Fiuza Martins HR, Silveira Gomes AR. Acute effects of stretching exercise on the soleus muscle of female aged rats. Acta Histochem. 2016;118(1):1-9.

11. ICLAS. Guidelines for Researcher. International Council for Laboratory Animal Science. 2012.

12. Kalu DN. The ovariectomizedrat model of postmenopausal bone loss. Bone Miner. 1991;15, 171-92.

13. Peviani SM, Gomes AR, Moreira RF, Moriscot AS, Salvini TF. Short bouts of stretching increase myo-D, myostatin and atrogin-1 in rat soleus muscle. Musc Nerv. 2007;35:363-70.

14. Stauber WT, Willems MET. Prevention of histopathologic changes from 30 repeated stretches of active rat skeletal muscle by long inter-stretch rest times. Eur J Appl Physiol. 2002;88,94-9.

15. Goldspink G. Sarcomere length during post natal growth of mammalian muscle fibres. J Cell Sci. 1968;3:539-48.

16. Williams, P.E.; Goldspink, G. Longitudinal growth of striated muscle fibres. J Cell Sci. 1971;9:751-61.

17. Cooper R, Mishra G, Clennel S, Guralnik J, Kuh D. Menopausal status and physical performance in midlife: finding from a British birth cohort study. Menopause. 2008;15:1079-85

18. Maltais ML, Desroches J, Dionne IJ. Changes in muscle mass and strength after menopause. J MuscNeur Interact. 2009;9:186-97.

19. McClung JM, Davis JM, Wilson MA, Goldsmith EC, Carson JA.. Estrogen status and skeletal muscle recovery from disuse atrophy. J Appl Physiol. 2006;100(6):2012-23.

20. Matsudo AS, Matsudo VKR, Neto TL. Impacto do envelhecimento nas variáveis antropométricas, neuromotoras e metabólicas da aptidão física. Rev Bras Ciên Mov. 2000;8(4):21-32.

21. Forbes GB. Body composition: overview. J Nutr. 1999;129(1):270S-2S.

22. Roubenoff R, Hughes VA. Sarcopenia: currentconcepts. J Gerontol A BiolSci Med Sci. 2000;55:M716-M24.

23. Hughes VA, Frontera WR, Roubenoff R, Evans WJ, Singh MA. Longitudinal changes in body composition in older men and women: role of body weight change and physical activity. Am J Clin. Nutcv. 2002;76(2):473-81.

24. Moreira MA, Brito MV, Brito NM, Filho MS. Estudo histomorfométrico do músculo esquelético de ratos em anestro. Acta Cir Bras. 2005;20:329-55.

25. Wu M, Fannin J, Rice KM, Wang B, Blough ER. Effect of aging on cellular mechanotransduction. Ageing Res Rev. 2011;10(1):1-15.

26. Gajdosik RL. Passive extensibility of skeletal muscle: review of the literature with clinical implications. Clin Biomech. 2001;16: 87-101. 
27. Tabary JC, Tabary C, Tardieu C, Tardieu G, Goldspink G. Physiological and structural changes in the cat's soleus muscle due to immobilization at different lengths by plaster casts. J Physiol. 1972;224:231-44.

28. Kokkonen J, Nelson AG, Tarawhiti T, Buckingham P, Winchester JB. Early-phase resistance training strength gains in novice lifters are enhanced by doing static stretching. J Strength Cond Res. 2010;24(2):502-6.

29. Cação-Benedini LO, Ribeiro PG, Gomes AR, Ywazaki $\mathrm{JL}$, Monte-Raso VV, Prado CM, Mattiello-Sverzut AC. Remobilization through stretching improves gait recovery in the rat. Acta Histochem. 2013;115(5):460-9.
30. Khan KM, Scott A. Mechanotherapy: how physical therapists prescription of exercise promotes tissue repair. J Sports Med. 2009;43:247-52.

31. Gajdosik RL. Effects of an eight-week stretching program on the passive elastic properties and function of the calf muscles of older women. Clin Biomech. 2005;20:973-83.

32. Marqueti RC, Prestes J, Stotzer US, Paschoal M, Leite RD, Perez SE, Selistre De Araujo HS. MMP-2, jumping exercise and nandrolone in skeletal muscle. Int J Sports Med. 2008;29(7):559-6. 